Article

\title{
Anthocyanin Induction by Drought Stress in the Calyx of Roselle Cultivars
}

\author{
Jeny Hinojosa-Gómez ${ }^{1}$, César San Martín-Hernández ${ }^{2}$, José B. Heredia ${ }^{1}{ }^{\mathbb{C}}$, Josefina León-Félix ${ }^{1}$, \\ Tomás Osuna-Enciso ${ }^{1}$ and María D. Muy-Rangel ${ }^{1, * \mathbb{D}}$ \\ 1 Centro de Investigación en Alimentación y Desarrollo, A.C. (CIAD) Coordinación Culiacán, \\ Carretera Eldorado km 5.5, Campo el Diez, C.P. 80110 Culiacán Rosales, Sinaloa, Mexico; \\ jeny.hinojosa@estudiantes.ciad.mx (J.H.-G.); jbheredia@ciad.mx (J.B.H.); ljosefina@ciad.mx (J.L.-F.); \\ osuna@ciad.mx (T.O.-E.) \\ 2 Colegio de Postgraduados, Carretera México-Texcoco km 36.5. Montecillo, C.P. 56230 Texcoco, \\ Estado de México, Mexico; sanmartin.cesar@colpos.mx \\ * Correspondence: mdmuy@ciad.mx; Tel.: +52-6674806950
}

Received: 11 February 2020; Accepted: 24 March 2020; Published: 28 March 2020

check for updates

\begin{abstract}
Abiotic factors can alter the chemical profile of crops and the number of compounds they contain. In this study, the anthocyanin and anthocyanidin contents, determined by ultra-performance liquid chromatography (UPLC-MS/MS), and the colour attributes of the calyces of three cultivars of Hibiscus sabdariffa subjected to three water stress regimes during the stage of physiological maturity were investigated. The total anthocyanin content in calyx increased relative to the control content under a $65 \%$ moisture irrigation regime. Among the cultivars, UAN16-2 showed the greatest increases in the contents of cyanidin, delphinidin 3-O-glucoside, cyanidin 3-O-glucoside, and cyanidin 3-O-sambubioside. The content of cyanidin 3-O-sambubioside showed the greatest increase, increasing by $55 \%$ relative to the control level. The contents of these compounds are correlated with colour attributes such as luminosity. Water stress under the $33 \%$ moisture condition during plant development led to decreased anthocyanin contents in all of the roselle cultivars.
\end{abstract}

Keywords: Hibiscus sabdariffa; anthocyanins; colour; drought stress; greenhouse; UPLC-MS/MS analysis

\section{Introduction}

Hibiscus sabdariffa L., a plant that grows in tropical and subtropical regions, is of considerable medicinal and economic value worldwide. It is valued in the food and nutraceutical industries as a source of minerals and fiber and thanks to its high contents of phenolic compounds, especially anthocyanins [1-5].

The colour of the calyx of this plant, known as roselle, varies from light to intense red and is related to its phytochemical content. Dark calyces have higher anthocyanin contents than do light calyces [6]. Delphinidin-3-sambubioside and cyanidine-3-sambubioside have been reported to be the two main anthocyanins in roselle and delphinidin-3-glucoside and cyanidin-3-glucoside are found in smaller amounts [7]. Approximately $85 \%$ of anthocyanins are attributable to delphinidin-3 sambubioside, which is considered the main source of the antioxidant capacity in roselle [8]. The conditions during crop production have strong effects on the concentrations of the main phenols in the calyx. The anthocyanin concentration of some varieties can differ by twofold owing to variation in environmental conditions and soil type at the production site [9]. Therefore, these factors should be considered when defining the chemical composition of a cultivar. 
The production of phytochemicals in fruits varies with the stage of development, stress level, defense mechanisms of the plant, genotype, and genotype*environment interactions [10,11]. It has been reported that water stress induces oxidative stress as a result of the formation of free radicals; to counteract the damage, the plant generates a signaling cascade, activating defense mechanisms that favor the production of secondary metabolites [12-15].

Although water stress adversely impacts the growth and development of plants [12], several studies have shown that low levels of water stress can induce the production of secondary metabolites, such as flavonoids, that function to regulate metabolic processes that serve in plant defense [16-19]. In addition, they serve as antioxidant compounds that reduce the turgor loss of the cell membrane, decreasing the cell lesions associated with stress [20].

The production environment of roselle plants has a strong effect on the concentrations of the main phenols present in the calyx. Variation of up to $70 \%$ in the contents of total soluble phenolic compounds and anthocyanins according to the production site has been reported [9]. In addition, the authors of [21] demonstrated that drought stress during roselle cultivation increases the anthocyanin content of the calyx by up to $28 \%$. However, it is unknown whether this effect on plant quality persists at different levels of drought and in different cultivars in commercial production.

The hypothesis evaluated in the present study is that moderate drought stress during roselle development modifies the contents of secondary metabolites and improves the contents of anthocyanins and some minerals and nutritional compounds in the calyx. The objective of this study was to evaluate the effect of water stress on anthocyanin content, which determines calyx colour, in three cultivars of roselle cultivated under three irrigation regimes under hydroponic and greenhouse conditions.

\section{Results and Discussion}

\subsection{Anthocyanins Produced Under Water Stress}

The H. sabdariffa calyx contained two anthocyanidins (cyanidin and delphinidin) and four anthocyanins (cyanidin 3-O-glucoside, cyanidin 3-sambubioside, delphinidin 3-O-glucoside, and delphinidin 3-sambubioside), as identified by ultra-performance liquid chromatography (UPLC) (Table 1).

Table 1. Compounds identified in H. sabdariffa extracts. RT, retention time.

\begin{tabular}{|c|c|c|c|c|c|}
\hline $\mathrm{RT}$ (min) & Analyte & Formula & Exact Mass $m / z$ & Scan Mode & Fragments \\
\hline 6.76 & Cyanidin & $\mathrm{C}_{15} \mathrm{H}_{11} \mathrm{O}_{6}^{+}$ & 287.05 & {$[\mathrm{M}]^{+}$} & $287.05,288.05$ \\
\hline 7.39 & Delphinidin & $\mathrm{C}_{15} \mathrm{H}_{11} \mathrm{O}_{7}$ & 303.05 & {$[\mathrm{M}]^{+}$} & $207.13,262.85,303.05$ \\
\hline 6.74 & $\begin{array}{c}\text { Cyanidin } \\
\text { 3-O-glucoside }\end{array}$ & $\mathrm{C}_{21} \mathrm{H}_{21} \mathrm{O}_{11}{ }^{+}$ & 449.1 & {$[\mathrm{M}]^{+}$} & $287.05,288.05,449.1$ \\
\hline 6.75 & $\begin{array}{c}\text { Cyanidin } \\
\text { 3-sambubioside }\end{array}$ & $\mathrm{C}_{26} \mathrm{H}_{29} \mathrm{O}_{15}{ }^{+}$ & 580.14 & {$[\mathrm{M}+\mathrm{H}]^{+}$} & $287.05,581.14,582.15$ \\
\hline 6.20 & $\begin{array}{l}\text { Delphinidin } \\
\text { 3-O-glucoside }\end{array}$ & $\mathrm{C}_{21} \mathrm{H}_{21} \mathrm{O}_{12}{ }^{+}$ & 465.1 & {$[\mathrm{M}]^{+}$} & $303.05,304.05,465.10$ \\
\hline 6.10 & $\begin{array}{c}\text { Delphinidin } \\
\text { 3-sambubioside }\end{array}$ & $\mathrm{C}_{26} \mathrm{H}_{29} \mathrm{O}_{16}{ }^{+}$ & 596.14 & {$[\mathrm{M}+\mathrm{H}]^{+}$} & $303.05,597.14,598.14$ \\
\hline
\end{tabular}

Among the identified compounds, cyanidin 3-O-glucoside and delphinidin were confirmed based on comparison with authentic standards. The remaining compounds were identified based on their retention time (RT) values, UV spectra, molecular weight, and molecular ion information (Figures 1 and 2) [22]. 

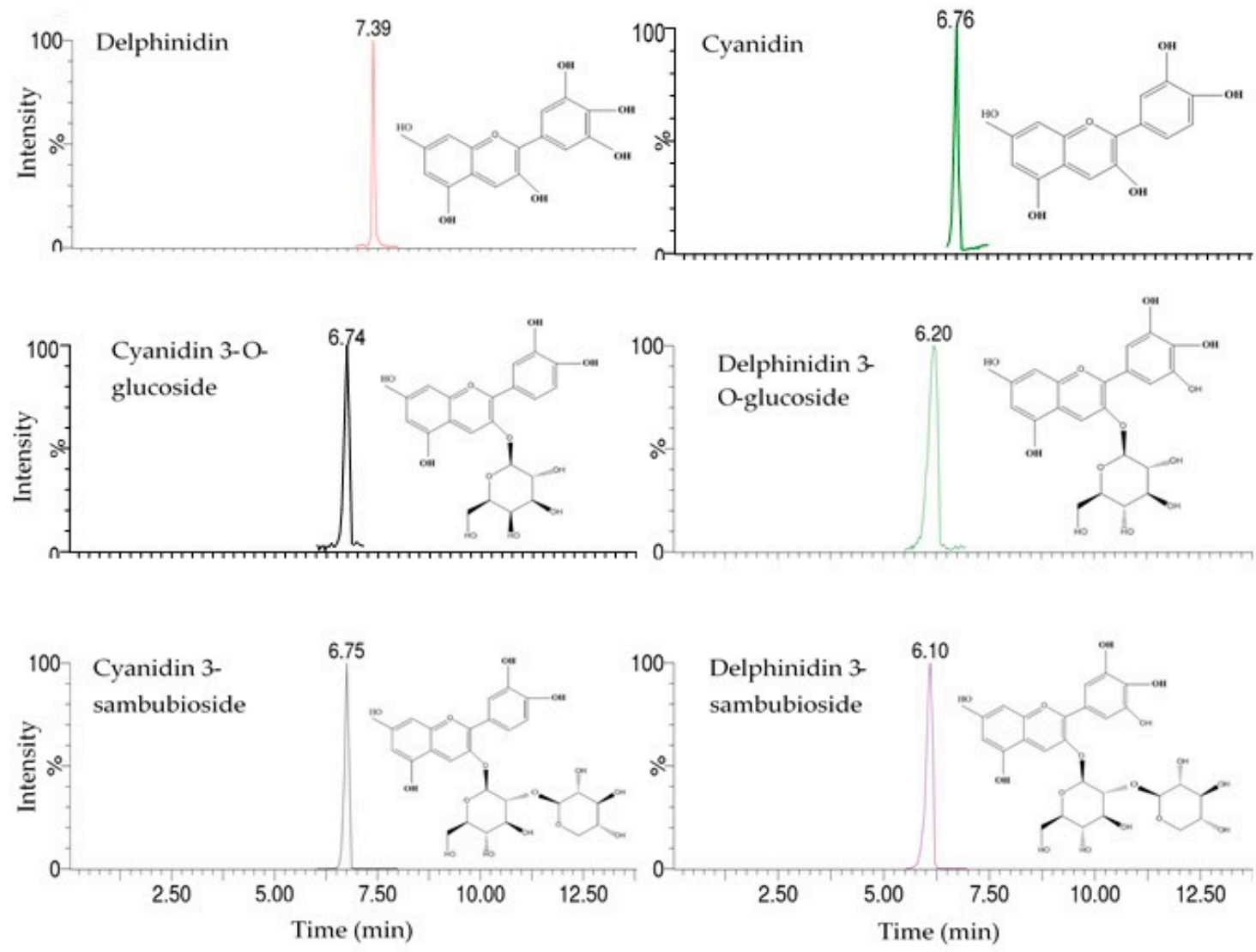

Figure 1. Chromatograms of anthocyanins and anthocyanidins determined in roselle calyx extracts.
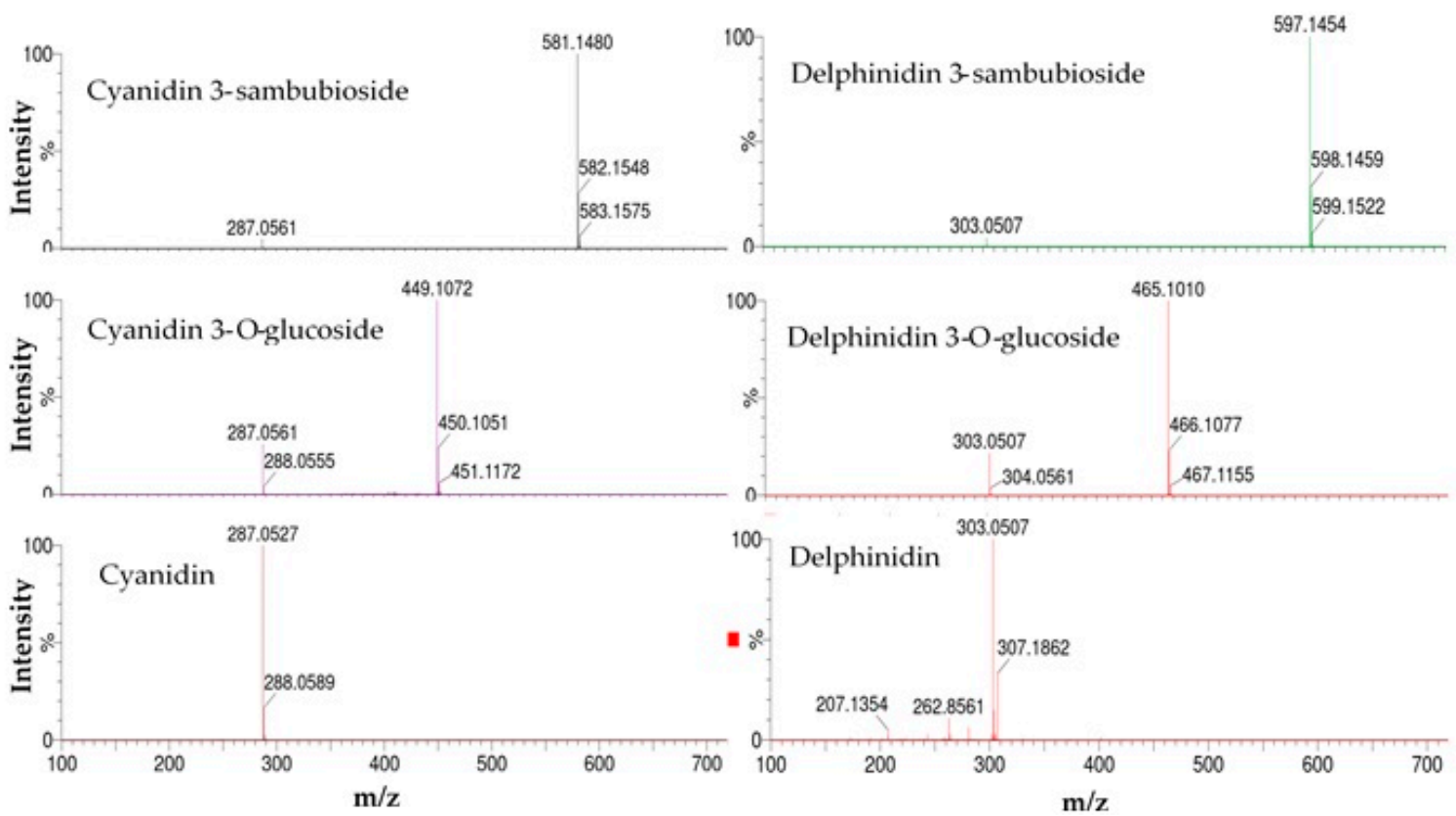

Figure 2. Mass spectra with a collision energy of $10 \mathrm{~V}$ for the identification of anthocyanins and anthocyanidins.

In all three roselle cultivars, the highest anthocyanin content was achieved in the plants treated with the irrigation regime of $65 \%$ (IR2) (Table 2). This result is consistent with the observation that the accumulation of anthocyanins in plants is regulated by various environmental stresses, such as drought, UV, injury, pathogen attack, and nutrient deficiency [23,24]. 
Table 2. Anthocyanins and anthocyanidins (mg EC3G $100 \mathrm{~g}^{-1} \mathrm{db}$ ) of the different genotypes of roselle calyces at three irrigation regimes of IR1, IR2, and IR3 (humidity content of $100 \%, 65 \%$, and $33 \%$, respectively) (mean $\pm \mathrm{SD}$ ).

\begin{tabular}{|c|c|c|c|c|c|c|c|c|}
\hline \multicolumn{2}{|c|}{ Cultivar/ Regimen } & \multirow{2}{*}{$\begin{array}{c}\text { Cyanidin } \\
40.4 \pm 9.5 \mathrm{de}\end{array}$} & \multirow{2}{*}{$\begin{array}{c}\text { Delphinidin } \\
15.9 \pm 2.9 \text { ef }\end{array}$} & \multirow{2}{*}{$\begin{array}{c}\begin{array}{r}\text { Cyanidin 3- } \\
\text { O-glucoside }\end{array} \\
8.6 \pm 1.8 \mathrm{de}\end{array}$} & \multirow{2}{*}{$\begin{array}{c}\begin{array}{c}\text { Cyanidin } \\
\text { 3-Sambubioside }\end{array} \\
184.3 \pm 13.2 \mathrm{de}\end{array}$} & \multirow{2}{*}{$\begin{array}{c}\begin{array}{c}\text { Delphinidin 3- } \\
\text { O-Glucoside }\end{array} \\
20.6 \pm 1.7 \mathrm{~cd}\end{array}$} & \multirow{2}{*}{$\begin{array}{l}\text { Delphinidin 3- } \\
\text { Sambubioside } \\
285.3 \pm 9.9 \mathrm{f}\end{array}$} & \multirow{2}{*}{$\begin{array}{c}\begin{array}{c}\text { Total } \\
\text { Anthocyanins }\end{array} \\
555.3 \pm 33.2 \mathrm{e}\end{array}$} \\
\hline \multirow{3}{*}{ UAN16-2 } & $\mathrm{IR}_{1}$ & & & & & & & \\
\hline & $\mathrm{IR}_{2}$ & $71.9 \pm 11 b c$ & $28.9 \pm 2.7 \mathrm{~d}$ & $16.5 \pm 0.1 b c$ & $405 \pm 11.1 \mathrm{~b}$ & $39.8 \pm 4.8 \mathrm{a}$ & $504.2 \pm 15 c d$ & $1066.3 \pm 44.5 c$ \\
\hline & $\mathrm{IR}_{3}$ & $21.6 \pm 2.4 \mathrm{e}$ & $4.3 \pm 0.8 \mathrm{f}$ & $6.3 \pm 1.5 \mathrm{e}$ & $98.6 \pm 3.7 f$ & $12.2 \pm 1.2 \mathrm{~d}$ & $134.1 \pm 13.1 \mathrm{~g}$ & $277.2 \pm 22.7 f$ \\
\hline \multirow{3}{*}{$4 \mathrm{Q} 4$} & $\mathrm{IR}_{1}$ & $35.9 \pm 6.8 \mathrm{de}$ & $11.3 \pm 7.5 c$ & $4.6 \pm 0.4 \mathrm{e}$ & $148.4 \pm 13.1 \mathrm{e}$ & $23.2 \pm 2.9 c$ & $325.3 \pm 8.8 \mathrm{ef}$ & $547.2 \pm 7.5 \mathrm{e}$ \\
\hline & $\mathrm{IR}_{2}$ & $55.9 \pm 4 \mathrm{~cd}$ & $23.1 \pm 2.4 \mathrm{ef}$ & $12.1 \pm 2 \mathrm{~cd}$ & $280.3 \pm 11 c$ & $34.9 \pm 3.2 \mathrm{ab}$ & $532.6 \pm 14.9 c$ & $938.9 \pm 7 d$ \\
\hline & $\mathrm{IR}_{3}$ & $42.4 \pm 2.5 \mathrm{de}$ & $8.4 \pm 1.1 \mathrm{f}$ & $7.6 \pm 1 \mathrm{de}$ & $211.8 \pm 24.2 \mathrm{~d}$ & $23.2 \pm 2.3 c$ & $328.1 \pm 7.1 \mathrm{e}$ & $621.5 \pm 36 \mathrm{e}$ \\
\hline \multirow{3}{*}{$\begin{array}{l}\text { Cruza } \\
\text { Negra }\end{array}$} & $\mathrm{IR}_{1}$ & $76.3 \pm 2.4 \mathrm{bc}$ & $78.9 \pm 1.5 b$ & $17.3 \pm 1.7 \mathrm{~b}$ & $507.7 \pm 1.4 a$ & $38.1 \pm 2.6 \mathrm{ab}$ & $615.9 \pm 8.3 b$ & $1350.1 \pm 10.1 b$ \\
\hline & $\mathrm{IR}_{2}$ & $104.3 \pm 2.4 a$ & $95.4 \pm 1.5 \mathrm{a}$ & $23.2 \pm 1.7 \mathrm{a}$ & $540 \pm 1.4 a$ & $44 \pm 2.6 a$ & $853.4 \pm 8.3 \mathrm{a}$ & $1660.3 \pm 1.1 \mathrm{a}$ \\
\hline & $\mathrm{IR}_{3}$ & $92.1 \pm 1.2 b c$ & $45.4 \pm 7.5 c$ & $9.1 \pm 1.3 \mathrm{de}$ & $373.5 \pm 5.1 b$ & $27.4 \pm 1.4 \mathrm{bc}$ & $488.1 \pm 7.4 \mathrm{~d}$ & $1019.8 \pm 6.4 \mathrm{~cd}$ \\
\hline
\end{tabular}

In each column, different letters mean significant differences between the samples according to the Tukey test $(p \leq 0.05)$

The highest contents of total anthocyanins were observed in cultivars UAN16-2 and Cruza Negra at IR2 (1066 and $1660 \mathrm{mg}$ EC3G $100 \mathrm{~g}^{-1} \mathrm{db}$, respectively) (Table 2). However, water stress under this irrigation regime (65\% moisture) induced higher contents of total anthocyanins in all three cultivars of roselle, with content increases of $23 \%, 72 \%$, and $92 \%$ for the cultivars Cruza Negra, 4Q4, and UAN16-2, respectively, relative to the control contents (under 100\% moisture). Under extreme water stress, anthocyanin contents were reduced in UAN16-2 and Cruza Negra. In plants, stress can inhibit the activity of the enzyme ascorbate peroxidase (APX), which functions to detoxify hydrogen peroxide by removing water from the vacuoles. As a result, $75 \%$ of the peroxide produced in the chloroplast migrates to the cytoplasm and is transported to the vacuole by means of aquaporins; a lack of APX activity stimulates the production of anthocyanins to replace APX function and prevent cell damage $[25,26]$. Studies on the effects of drought and osmotic stress on polyphenols in different species indicate that polyphenol contents can increase or decrease depending on plant species and the type and intensity of stress [27], as observed in the present study. Increases have been reported in the total phenolic content and in betalains in red beets under drought-induced stress [28]. Furthermore, the concentration of flavonoids was shown to generally decrease in five cultivars of cherry tomatoes under water stress at $50 \%$ substrate humidity [29].

Under water stress (IR2), the cultivar UAN16-2 had the highest contents of cyanidin 3-O-sambubioside and delphinidin 3-O-sambubioside among the cultivars, with increments of $54 \%$ and $43 \%$, respectively, relative to the control contents (under IR1). This suggests that the stress favored the accumulation of anthocyanins with the $O$-sambubioside glucoside, possibly to store compounds with a high number of sugars as energy reserves. These results are interesting because UAN16-2 produces calyces of low-saturation red tones under normal conditions; however, under drought exposure, the red colour of the calyces becomes saturated (Figure 3), and the calyces become similar in colour and pigment content to those of $4 \mathrm{Q} 4$. 


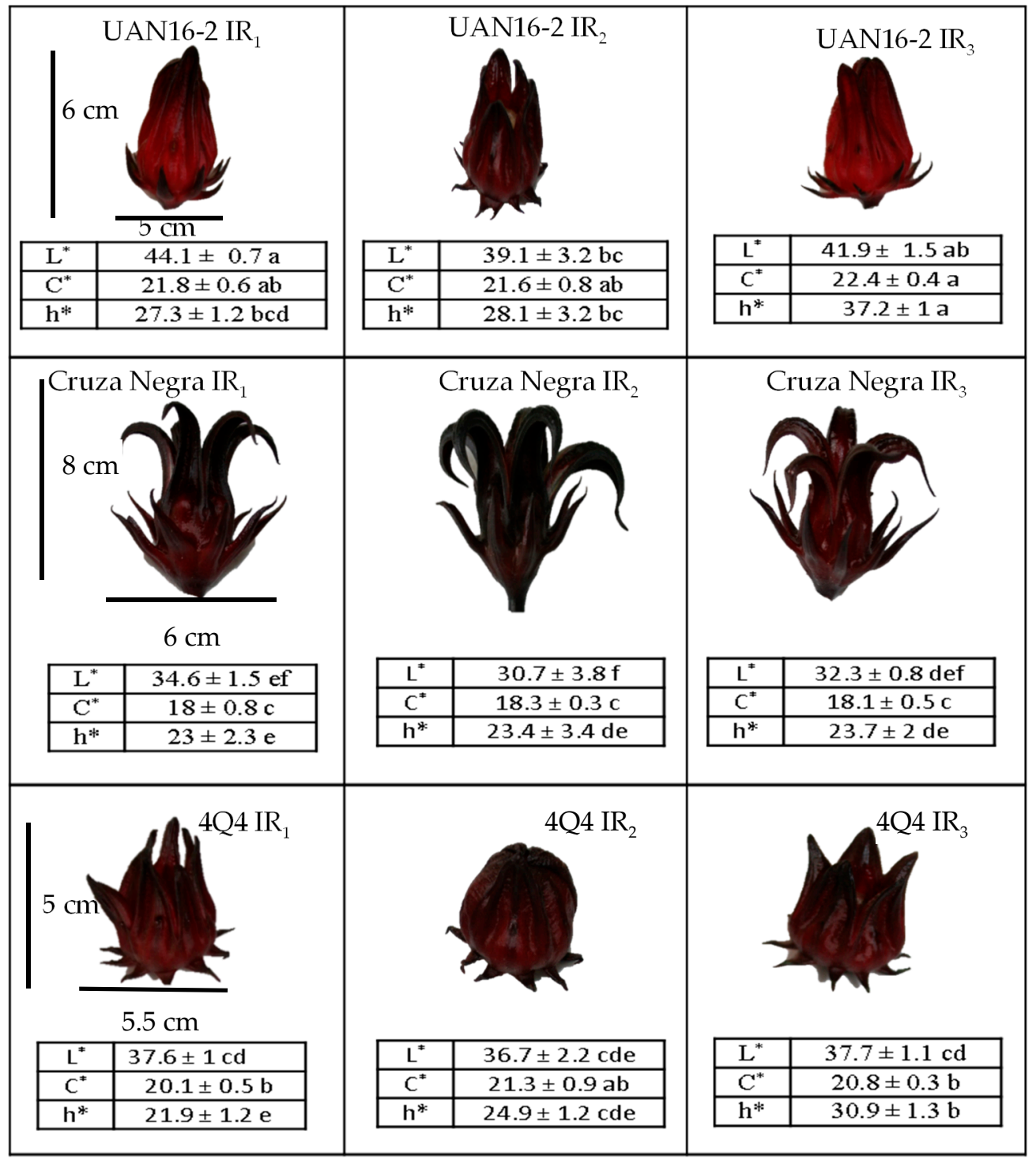

Figure 3. Color parameters and calyx appearance of different roselle genotypes in three irrigation regimes (IR1 $=100 \%$, IR2 $=65 \%$, and IR3 $=33 \%$ humidity). Means with different letters within columns and rows per response variable show significant differences according to the Tukey test $(p \leq 0.05)$.

\subsection{Roselle Calyx Colour}

In the colour analysis (Figure 3$)$, the control calyces showed significant differences $(p \leq 0.05)$ in luminosity (L), chromaticity, and hue angle $\left({ }^{\circ}\right.$ Hue) among the cultivars, with Cruza Negra showing the lowest hue $\left({ }^{\circ}\right.$ Hue $\left.=23\right)$, corresponding to a dark red colour. The colour of the calyces reflected the content of anthocyanins (which are responsible for the red colour). However, the stress conditions yielded notable changes from control conditions only in the luminosity of the roselle calyx in the three cultivars, which was lower under water stress than under $100 \%$ moisture (Table 2). In general, the colour of the roselle calyx is very varied and can present values of luminosity between 29 and 49 , chromaticity between 18 and 27, and hue angle between 13 and 28 [2], which correspond to calyces of light red, deep red, and dark brown red. However, each variety of roselle has market value owing to its visual quality, size, anthocyanin content, and chemical characteristics such as acidity and aroma [6]. 


\section{Materials and Methods}

\subsection{Field Experiment}

The experiment was conducted in a greenhouse at the Food and Development Research Center (CIAD), A.C., Culiacán Unit, located in Sinaloa, Mexico (28 m altitude, $24^{\circ} 44^{\prime} 02$ "N and 107²7'16" W), from January to May 2017. Three cultivars of Hibiscus sabdariffa L. (Cruza Negra, UAN16-2 and 4Q4) provided by the Autonomous University of Nayarit, Mexico, were studied under hydroponic conditions in greenhouses. To monitor the environmental conditions, a Hobo Data Logger was placed within the canopy of the plants to record daily temperature and relative humidity (Figure 4).

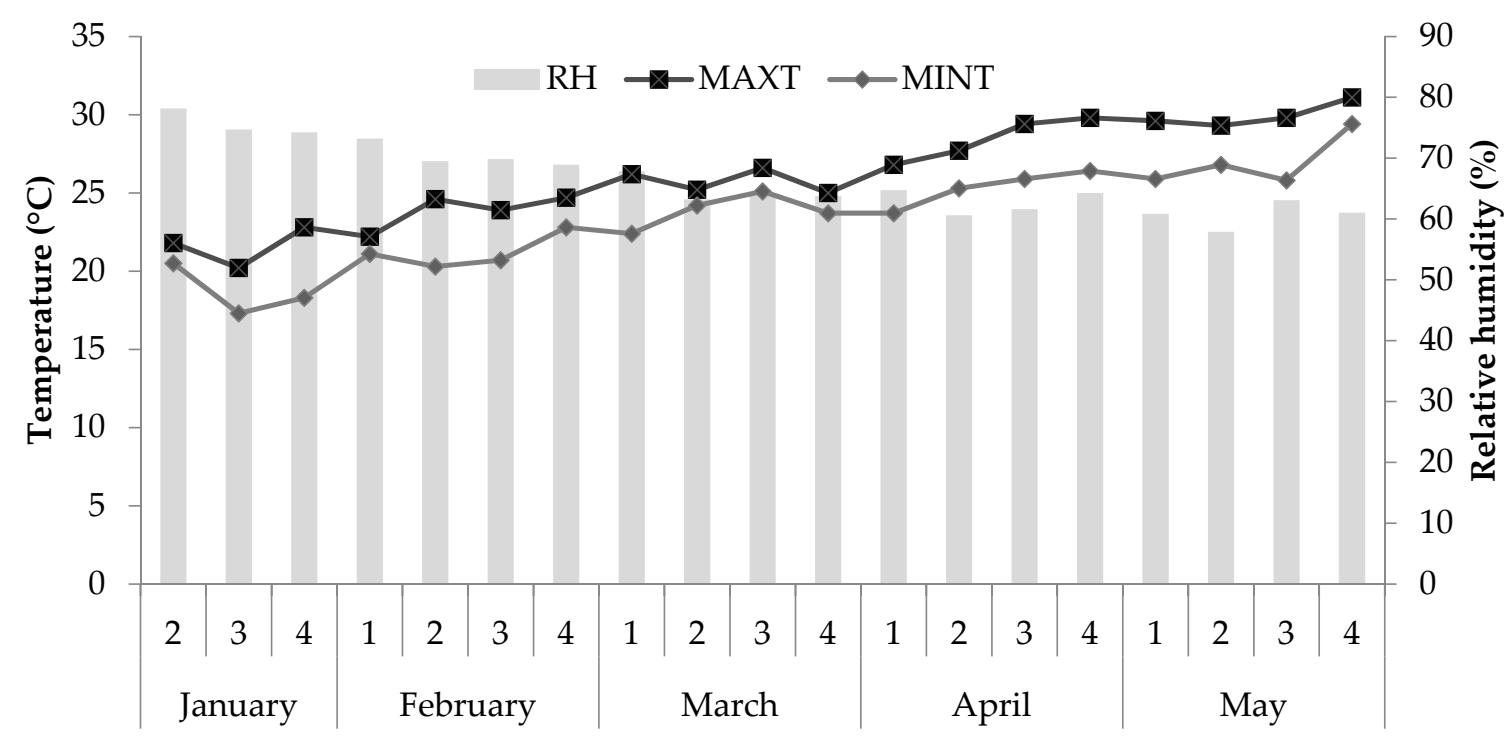

Weeks of development of the cultivation of Hibiscus sabdariffa (2017)

Figure 4. Weekly average of relative humidity $(\mathrm{RH})$ and maximum (MAXT) and minimum temperatures (MINT) during the cultivation of roselle.

The seeds were planted in germination trays of 120 cavities in a mixture of peat moss/agrolite $(70: 30 v / v)$. At 14 days after germination, the seedlings were transplanted in a greenhouse. Each seedling was placed in a polyethylene bag containing $13 \mathrm{~L}$ of a previously characterized potting mixture (60\% fluvisol soil and $40 \%$ coconut fiber) (Table 3 ) with a $0.50 \mathrm{~m}$ planting distance and $1.0 \mathrm{~m}$ between rows.

Table 3. Physicochemical profile of the substrate.

\begin{tabular}{|c|c|}
\hline Characteristic & Value \\
\hline $\mathrm{pH}$ & 6.44 \\
\hline Electrical conductivity $\left(\mathrm{dS} \mathrm{m}^{-1}\right)$ & 1.14 \\
\hline Sodium $\left(\mathrm{mg} \mathrm{kg}^{-1}\right)$ & 528.99 \\
\hline Potassium $\left(\mathrm{mg} \mathrm{kg}^{-1}\right)$ & 801.28 \\
\hline Calcium (mg kg$\left.{ }^{-1}\right)$ & 5025.65 \\
\hline Magnesium $\left(\mathrm{mg} \mathrm{kg}^{-1}\right)$ & 5025.65 \\
\hline Iron $\left(\mathrm{mg} \mathrm{kg}^{-1}\right)$ & 990.09 \\
\hline Manganese $\left(\mathrm{mg} \mathrm{kg}^{-1}\right)$ & 48.86 \\
\hline Zinc $\left(\mathrm{mg} \mathrm{kg}^{-1}\right)$ & 6.7 \\
\hline Copper $\left(\mathrm{mg} \mathrm{kg}^{-1}\right)$ & 2.68 \\
\hline $\begin{array}{l}\text { Cationic exchange capacity } \\
\quad(\text { CEC) (meq 100g-1) }\end{array}$ & 37.58 \\
\hline Phosphorus (mg kg-1) & 89.95 \\
\hline Nitrates $\left(\mathrm{mg} \mathrm{kg}^{-1}\right)$ & 104.69 \\
\hline
\end{tabular}


A two-factor completely randomized design was used, with three levels per factor: factor 1 , cultivar (Cruza Negra, UAN16-2 and 4Q4); and factor 2, substrate moisture level (100\%, 65\%, and 33\%). There were three treatments in total, with each unit represented by five plants (one of which was used to monitor substrate moisture) and three experimental replicates per treatment; in addition, there were 56 board plants. To obtain the moisture retention curve of the soil mixture, three samples were taken, pre-saturated, and then subjected to different stresses by the pressure membrane method, applying the principle of hydrostatic equilibrium [30]. Then, on the basis of the curve, three irrigation regimes (IR) were selected: $100 \%$ (343 $\mathrm{mL} \mathrm{L}^{-1}$ soil mixture) humidity at field capacity (FC) (IR1: irrigation regime without deficit in available soil moisture for the plant), $65 \%$ of the FC moisture required $\left(293 \mathrm{~mL} \mathrm{~L}^{-1}\right)$ (IR2: irrigation regime with moderate soil moisture deficit), and $33 \%$ of the FC required $\left(236 \mathrm{~mL} \mathrm{~L}^{-1}\right)$ (IR3: irrigation level with high soil moisture deficit), all with a moisture range of \pm 5\% (Figure 5).

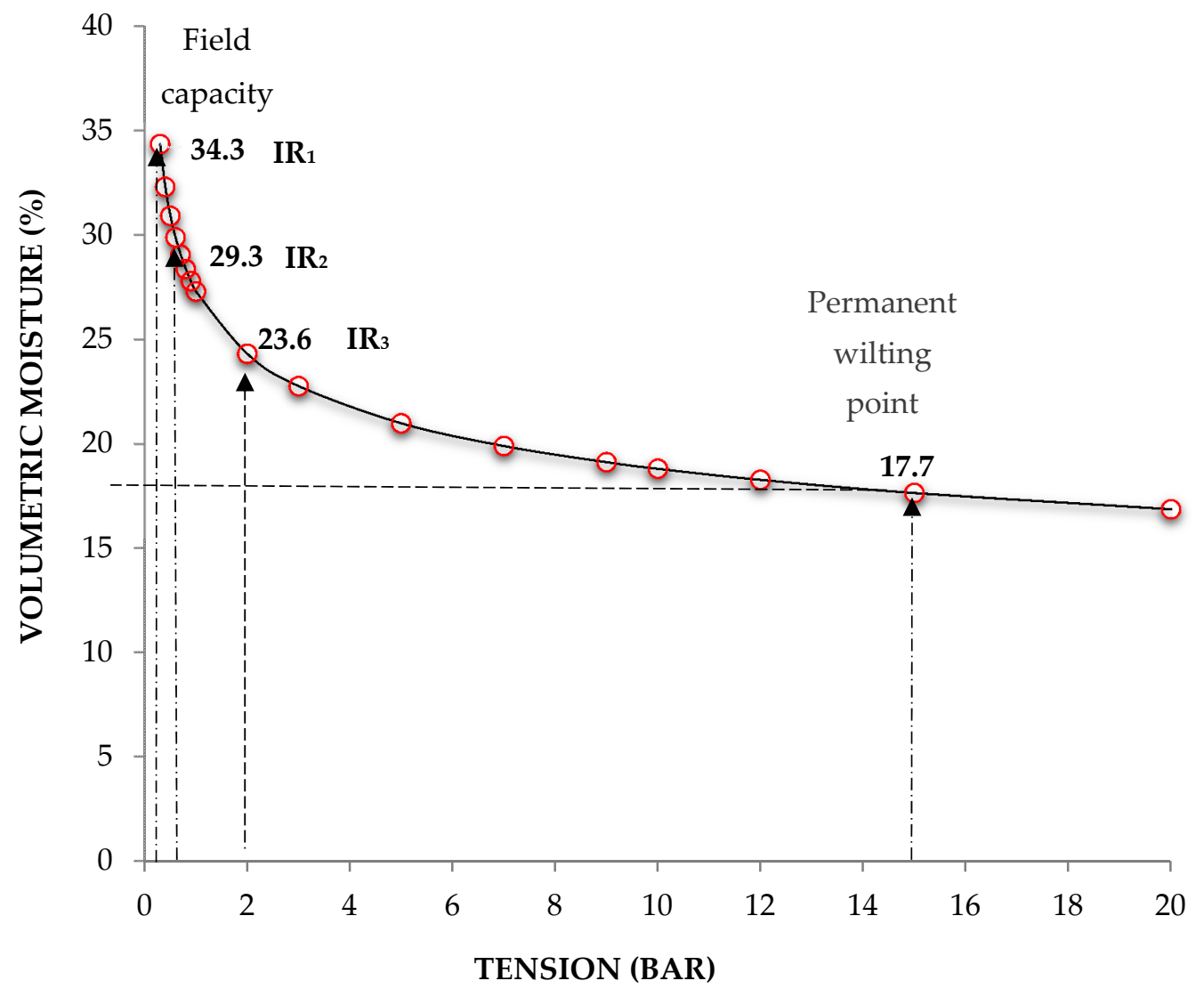

Figure 5. Water retention curve of the substrate.

Steiner solution [31] with an electrical conductivity of $2 \mathrm{dS} \mathrm{m}^{-1}$ and $\mathrm{pH}$ at 5.8 was supplied through drip irrigation eight times a day for $5 \mathrm{~min}$ using $4 \mathrm{~L} \mathrm{~h}^{-1}$ drippers during the first 90 days of cultivation. From calyx development until harvest (168 days after sowing), the moisture treatments were applied (varying the irrigation dose), and the moisture level in the substrate was continually monitored by the gravimetric method.

The plants were harvested at the commercial maturity stage (at the opening of the capsule, which exposes the seeds), and the calyces were separated manually from the capsules. The calyces were frozen at $-20{ }^{\circ} \mathrm{C}$, lyophilized, and stored at $-60{ }^{\circ} \mathrm{C}$.

\subsection{Identification and Quantification of Anthocyanins}

The extraction of anthocyanins from the roselle calyces was performed according to [32] with slight modifications. One milligram of lyophilized calyx was weighed, and $10 \mathrm{~mL}$ of methanol acidified 
with $1 \% \mathrm{HCl}$ was added; the solution was then refrigerated at $4{ }^{\circ} \mathrm{C}$ overnight. Subsequently, the solution was filtered with Whatman No. 1 filter paper in a vacuum pump, and $10 \mathrm{~mL}$ of methanol acidified with $1 \% \mathrm{HCl}$ was added to wash the anthocyanin residues. The sample was then evaporated to dryness in a rotary evaporator at $45 \mathrm{rpm}$ at $30{ }^{\circ} \mathrm{C}$, and then re-dissolved in $10 \mathrm{~mL}$ of $0.01 \% \mathrm{HCl}$ (Milli-Q water). To purify the anthocyanins, $5 \mathrm{~mL}$ of the extract was added to a separatory funnel and stirred with $10 \mathrm{~mL}$ of petroleum ether to collect the colored phase. The sample was again added to the separatory funnel, $10 \mathrm{~mL}$ of ethyl acetate was added, the mixture was stirred, and the colored phase was collected. One milliliter of the extract was absorbed in a Sep-Pak C-18 cartridge (Waters Assoc., Milford, MA, USA) previously activated with $1 \mathrm{~mL}$ of methanol and $1 \mathrm{~mL}$ of $0.01 \% \mathrm{HCl}$. The absorbed extract was discarded; then, $2 \mathrm{~mL}$ of $0.01 \%$ aqueous $\mathrm{HCl}$ was filtered and discarded, and the extract was filtered with $4 \mathrm{~mL}$ of methanol acidified with $0.01 \% \mathrm{HCl}$ (Milli-Q water) and the extract was evaporated. After drying in a rotary evaporator at $35^{\circ} \mathrm{C}$, the extract was re-dissolved in $1 \mathrm{~mL}$ of Milli-Q water acidified with $0.01 \% \mathrm{HCl}$. Finally, the extract was filtered on a nylon filter with a diameter of $13 \mathrm{~mm}$ and a particle size of $0.2 \mu \mathrm{m}$ (Agilent Technologies), and stored in a dark vial at $-20{ }^{\circ} \mathrm{C}$ for further analysis [33].

Anthocyanidins and anthocyanins (cyanidin, delphinidin, cyanidin-3-O-glucoside, cyanidin 3-sambubioside, delphinidin 3-O-glucoside, delphinidin 3-sambubioside) were identified and quantified via ultra-performance liquid chromatography (UPLC-MS/MS) Acquity class $H$ (Waters) instrument coupled to a mass analyzer G2-XS Qtof (quadrupole and time-of-flight) using a procedure modified from [34]. Briefly, compounds were separated on a C18 column (Acquity BEH, $1.7 \mu \mathrm{m}$, $2.1 \mathrm{~mm} \times 50 \mathrm{~mm}$, Waters, 186,002,350) maintained at room temperature. Mobile phase A was a 99:1 v/v formic acid/water mixture, and mobile phase B was $100 \%$ acetonitrile. The injection volume was $1 \mu \mathrm{L}$. The mobile phase gradient is summarized in Table 4.

Table 4. Applied ultra-performance liquid chromatography (UPLC) gradient parameters for the elution of anthocyanins.

\begin{tabular}{cccc}
\hline Time (min) & Solvent A (\%) & Solvent B (\%) & Flow rate $(\mu \mathrm{L} / \mathbf{m i n})$ \\
\hline 0 & 100 & 0 & 400 \\
5 & 91 & 9 & 400 \\
7 & 85 & 15 & 400 \\
8 & 0 & 100 & 400 \\
10 & 0 & 100 & 400 \\
10.1 & 100 & 0 & 400 \\
13 & 100 & 0 & 400 \\
\hline
\end{tabular}

Electrospray ionization (ESI) was used. $[\mathrm{M}]^{-}$is given as the identity of the molecular ion instead of $[\mathrm{M}+\mathrm{H}]^{-}$because, in acidic conditions, there are anthocyanins, such as flavylium cations [35], with a collision energy of $10 \mathrm{~V}$. The electrospray capillary voltage was $1.5 \mathrm{kV}$, the source temperature was $150{ }^{\circ} \mathrm{C}$, the desolvation temperature was $350{ }^{\circ} \mathrm{C}$, the gas (nitrogen) was provided at a flow rate of $500 \mathrm{~L} \mathrm{~h}^{-1}$, the cone voltage was $40 \mathrm{~V}$, and the collision gas was $20 \mathrm{~V}$. The compounds were identified based on the literature [22] and quantified based on curves of HPLC-grade analytical standards of cyanidin 3-O-glucoside (CAS No. 7084-24-4) and delphinidin (CAS No. 528-53-0), with a degree of purity $\geq 95 \%$ for both (Sigma-Aldrich, USA). On the basis of this methodology, the analysis method is considered reliable.

\subsection{Calibration Curves}

Each of the standards ( $1 \mathrm{~g}$ ) was diluted in $25 \mathrm{ml}$ of UPLC grade methanol to reach a final concentration of $38,000 \mathrm{ng} \mathrm{mL}^{-1}$ (considering 95\% purity). Stock solution of the two analytes was diluted to appropriate concentrations (25 dilutions from 0 to $38,000 \mathrm{ng} \mathrm{mL}^{-1}$ with proportional increases of $253.3 \mathrm{ng} \mathrm{mL}^{-1}$ ) For each calibration curve, eight of the previous concentrations were used (63.33, $253.33,760,1520,2026.67,5066.67,12,666.67$, and 22,800 $\mathrm{ng} \mathrm{mL} \mathrm{mL}^{-1}$ ), and each point was measured 
in triplicate for the construction of calibration curves. The calibration curves were constructed by plotting the peak area (extracted ion chromatograms (EIC) signal of MS) versus the concentration of each analyte. For each point of the curve, three injections of the indicated concentration were made.

\subsection{Colour Analysis}

The colour attributes of the roselle calyx were obtained in the CIELCh colour space using a spectrophotometer (CM-700d; Konica Minolta, Ramsey, New Jersey, USA). The luminosity (L), hue angle $($ Hue $=\arctan b / a)$, and chromaticity $\left(\right.$ Chroma $\left.=\sqrt{ }\left[a^{2}+b^{2}\right]\right)$ were obtained with OnColor QC version 5 (CyberChrome, Stone Ridge, NY, USA) [2].

\subsection{Statistical Analysis}

A completely randomized factorial design was employed with two factors, each with three levels: soil moisture $(100 \%, 65 \%$, and 33\%) and cultivar (Cruza Negra, UAN16-2 and 4Q4). The data were analyzed by analysis of variance (ANOVA), and the means were compared with the Tukey test $(p \leq 0.05)$ with Minitab 17 software.

\section{Conclusions}

It is possible to increase the anthocyanin content in the roselle calyx by modifying agricultural practices, for example, by applying decreased irrigation during the stage of physiological maturity of the fruit under greenhouse conditions. The present study found that a moderate water stress irrigation regime (65\% moisture) achieved an increase in anthocyanins, and that UAN16-2 was the cultivar with the best response to water stress, exhibiting significant changes in pigment synthesis. Extreme water stress (33\% moisture) affected the concentrations of calyx pigments. Anthocyanin content was correlated with the colour properties of the roselle calyces.

Author Contributions: J.H.-G. and M.D.M.-R., conceptualization; J.H.-G. and C.S.M.-H., formal analysis; C.S.M.-H. and J.L.-F., validation; J.B.H., methodology and resources; J.L.-F., visualization; T.O.-E. and M.D.M.-R., supervision; J.H.-G., investigation; M.D.M.-R., project administration; J.H.-G., M.D.M.-R., C.S.M.-H., J.L.-F., J.B.H., and T.O.-E., wrote and edited the original draft. All authors have read and agreed to the published version of the manuscript.

Funding: This research received no external funding.

Conflicts of Interest: The authors declare no conflict of interest.

\section{References}

1. Ali, B.H.; Wabel, N.A.L.; Blunden, G. Phytochemical, pharmacological and toxicological aspects of Hibiscus sabdariffa L.: A review. Phytother. Res. 2005, 19, 369-375. [CrossRef] [PubMed]

2. Hinojosa-Gómez, J.; San Martin-Hernández, C.; Heredia, J.B.; León-Félix, J.; Osuna-Enciso, T.; Muy-Rangel, M.D. Roselle (Hibiscus sabdariffa L.) cultivars calyx produced hydroponically: Physicochemical and nutritional quality. Chil. J. Agric. Res. 2018, 78, 478-485. [CrossRef]

3. Fernández-Arroyo, S.; Rodríguez-Medina, I.C.; Beltrán-Debón, R.; Pasini, F.; Joven, J.; Micol, V.; Segura-Carreero, A.; Fernández-Gutiérrez, A. Quantification of the polyphenolic fraction and in vitro antioxidant and in vivo anti-hyperlipemic activities of Hibiscus sabdariffa aqueous extract. Food Res. Int. 2011, 44, 1490-1495. [CrossRef]

4. Hopkins, A.L.; Lamm, M.G.; Funk, J.L.; Ritenbaugh, C. Hibiscus sabdariffa L. in the treatment of hypertension and hyperlipidemia: A comprehensive review of animal and human studies. Fitoterapia 2013, 85, 84-94. [CrossRef] [PubMed]

5. Sindi, H.A.; Marshall, L.J.; Morgan, M.R.A. Comparative chemical and biochemical analysis of extracts of Hibiscus sabdariffa. Food Chem. 2014, 164, 23-29. [CrossRef] [PubMed]

6. Christian, K.R.; Jackson, J.C. Changes in total phenolic and monomeric anthocyanin composition and antioxidant activity of three varieties of sorrel (Hibiscus sabdariffa) during maturity. J. Food Compos. Anal. 2009, 22, 663-667. [CrossRef] 
7. Cissé, M.; Vaillant, F.; Pallet, D.; Dornier, M. Selecting ultrafiltration and nanofiltration membranes to concentrate anthocyanins from roselle extract (Hibiscus sabdariffa L.). Food Res. Int. 2011, 44, 2607-2614. [CrossRef]

8. Diessana, A.; Parkouda, C.; Cissé, M.; Diawara, B.; Dicko, M.H. Optimization of aqueous extraction of anthocyanins from Hibiscus sabdariffa L. calyces for food application. Food Sci. Qual. Manag. 2015, 45, 23-31.

9. Juliani, H.R.; Welch, C.R.; Wu, Q.; Diouf, B.; Malainy, D.; Simon, J.E. Chemistry and Quality of Hibiscus (Hibiscus sabdariffa) for Developing the Natural-Product Industry in Senegal. J. Food Sci. 2009, 74, S113-S121. [CrossRef]

10. Ren, F.; Reilly, K.; Kerry, J.P.; Gaffney, M.; Hossain, M.; Rai, D.K. Higher Antioxidant Activity, Total Flavonols, and Specific Quercetin Glucosides in Two Different Onion (Allium cepa L.) Varieties Grown under Organic Production: Results from a 6-Year Field Study. J. Agric. Food Chem. 2017, 65, 5122-5132. [CrossRef]

11. Teixeira, A.; Eiras-Dias, J.; Castellarin, S.; Gerós, H. Berry Phenolics of Grapevine under Challenging Environments. Int. J. Mol. Sci. 2013, 14, 18711-18739. [CrossRef] [PubMed]

12. Guha, A.; Sengupta, D.; Kumar Rasineni, G.; Ramachandra Reddy, A. An integrated diagnostic approach to understand drought tolerance in mulberry (Morus indica L.). Flora 2010, 205, 144-151. [CrossRef]

13. Mittler, R.; Blumwald, E. The roles of ROS and ABA in systemic acquired acclimation. Plant Cell 2015, 27, 64-70. [CrossRef] [PubMed]

14. Rejeb, I.; Pastor, V.; Mauch-Mani, B. Plant Responses to Simultaneous Biotic and Abiotic Stress: Molecular Mechanisms. Plants 2014, 3, 458-475. [CrossRef]

15. Evans, D.; Al-hamdani, S. Selected physiological responses of roselle (Hibiscus sabdariffa) to drought stress. J. Exp. Biol. 2015, 3, 500-507.

16. Basu, S.; Roychoudhury, A.; Saha, P.P.; Sengupta, D.N. Differential antioxidative responses of indica rice cultivars to drought stress. Plant Growth Regul. 2010, 60, 51-59. [CrossRef]

17. Bettaieb Rebey, I.; Jabri-Karoui, I.; Hamrouni-Sellami, I.; Bourgou, S.; Limam, F.; Marzouk, B. Effect of drought on the biochemical composition and antioxidant activities of cumin (Cuminum cyminum L.) seeds. Ind. Crop. Prod. 2012, 36, 238-245. [CrossRef]

18. Cogo, S.L.P.; Chaves, F.C.; Schirmer, M.A.; Zambiazi, R.C.; Nora, L.; Silva, J.A.; Rombaldi, C.V. Low soil water content during growth contributes to preservation of green colour and bioactive compounds of cold-stored broccoli (Brassica oleraceae L.) florets. Postharvest Biol. Technol. 2011, 60, 158-163. [CrossRef]

19. Mundim, F.M.; Pringle, E.G. Whole-Plant Metabolic Allocation Under Water Stress. Front. Plant Sci. 2018, 9 , 852. [CrossRef]

20. Wróbel, M.; Karama, M.; Amarowicz, R.; Fr Czek, E.; Weidner, S. Metabolism of phenolic compounds in Vitis riparia seeds during stratification and during germination under optimal and low temperature stress conditions. Acta Physiol. Plant. 2005, 27, 313-320. [CrossRef]

21. Ifie, I.; Ifie, B.E.; Ibitoye, D.O.; Marshall, L.J.; Williamson, G. Seasonal variation in Hibiscus sabdariffa (Roselle) calyx phytochemical profile, soluble solids and $\alpha$-glucosidase inhibition. Food Chem. 2018, 261, 164-168. [CrossRef] [PubMed]

22. Sa, M.; Showalter, M. MassBank of North America (MoNA). 2017. Available online: http://mona.fiehnlab. ucdavis.edu/spectra/search (accessed on 19 November 2017).

23. Akula, R.; Ravishankar, G.A. Influence of abiotic stress signals on secondary metabolites in plants. Plant Signal. Behav. 2011, 6, 1720-1731. [CrossRef] [PubMed]

24. Kassim, A.; Poette, J.; Paterson, A.; Zait, D.; McCallum, S.; Woodhead, M.; Graham, J. Environmental and seasonal influences on red raspberry anthocyanin antioxidant contents and identification of quantitative traits loci (QTL). Mol. Nutr. Food Res. 2009, 53, 625-634. [CrossRef] [PubMed]

25. Foyer, C.H.; Noctor, G. Redox Regulation in Photosynthetic Organisms: Signaling, Acclimation, and Practical Implications. Antioxid. Redox Signal. 2009, 11, 861-905. [CrossRef]

26. Murata, N.; Allakhverdiev, S.I.; Nishiyama, Y. The mechanism of photoinhibition in vivo: Re-evaluation of the roles of catalase, $\alpha$-tocopherol, non-photochemical quenching, and electron transport. Biochim. Biophys. Acta. 2012, 1817, 1127-1133. [CrossRef]

27. Popović, B.M.; Štajner, D.; Ždero-Pavlović, R.; Tumbas-Šaponjac, V.; Čanadanović-Brunet, J.; Orlović, S. Water stress induces changes in polyphenol profile and antioxidant capacity in poplar plants (Populus spp.). Plant Physiol. Biochem. 2016, 105, 242-250. [CrossRef] 
28. Stagnari, F.; Galieni, A.; Speca, S.; Pisante, M. Water stress effects on growth, yield and quality traits of red beet. Sci. Hortic. 2014, 165, 13-22. [CrossRef]

29. Sánchez-Rodríguez, E.; Moreno, D.A.; Ferreres, F.; Rubio-Wilhelmi, M.M.; Ruiz, J.M. Differential responses of five cherry tomato varieties to water stress: Changes on phenolic metabolites and related enzymes. Phytochemistry 2011, 72, 723-729. [CrossRef]

30. Osuna-Ceja, E.; Figueroa-Sandoval, B.; Oleschko, K.; Flores-Delgadillo, M.L.; Martínez-Menes, M.R.; González-Cossío, F.V. Effect of soil structure on corn root development. Agrociencia 2006, 40, 27-38.

31. Steiner, A.A. A universal method for preparing nutrient solutions of a certain desired composition. Plant Soil 1961, 15, 134-154. [CrossRef]

32. Hong, V.; Wrolstad, R.E. Use of HPLC Separation/Photodiode Array Detection for Characterization of Anthocyanins. J. Agric. Food Chem. 1990, 38, 708-715. [CrossRef]

33. Fang, Z.X.; Zhang, M.; Wang, L.X.; Sun, J.C. Identification of anthocyanin in Bayberry (Myrica rubra Sieb. et Zucc.) by HAPLC-DAD-ESIMS and GC. J. Food Drug Anal. 2006, 14, 368-372.

34. Nagy, K.; Redeuil, K.; Bertholet, R.; Steiling, H.; Kussmann, M. Quantification of anthocyanins and flavonols in milk-based food products by ultra-performance liquid chromatography-tandem mass spectrometry. Anal. Chem. 2009, 81, 6347-6356. [CrossRef] [PubMed]

35. Nielsen, I.L.F.; Dragsted, L.O.; Ravn-haren, G.; Freese, R.; Rasmussen, S.E. Absorption and excretion of black currant anthocyanins in humans and watanabe heritable hyperlipidemic rabbits. J. Agric. Food Chem. 2003, 51, 2813-2820. [CrossRef]

Sample Availability: Samples of the compounds are not available from the authors.

(C) 2020 by the authors. Licensee MDPI, Basel, Switzerland. This article is an open access article distributed under the terms and conditions of the Creative Commons Attribution (CC BY) license (http://creativecommons.org/licenses/by/4.0/). 